5 years. Consequently, if a 5 year old boy has an observed 12 month height velocity at the mean value for the population - that is, $6.27 \mathrm{~cm}$ a year on standard charts-the $95 \%$ confidence interval for his true velocity ranges from the 25 th centile to the 75 th. However, if another boy aged 2 years also has an observed velocity on the 50 th centile $-8.31 \mathrm{~cm}$ a year in this case - the $95 \%$ confidence interval ranges from the 21 st centile to the 79 th.

This degree of imprecision in determining the rate of growth, at any age, means that in practice the calculation of a single velocity, even over 12 months, is of limited clinical use. ${ }^{3}$ The measurement of height must therefore begin at the earliest possible age and be repeated at frequent intervals to observe the trend, ideally by the same observer. The data for each child measured should be plotted on an individual height chart, and an explanation sought for unexpected changes in centile. AB.

DV is supported by Kabi Pharmacia UK Ltd and Sweden

1 Voss LD, Bailey BJR, Cumming K, Wilkin TJ, Betts PR. The reliability of height measurement. Arch Dis Child 1990;65:1340-4.

2 Tanner JM, Whitehouse RH, Takaishi M. Standards from birth to maturity fo height, weight, height velocity and weight velocity: British children 1965. Part II. Arch Dis Child 1966;41:613-5.

3 Voss LD, Wilkin TJ, Bailey BJR, Betts PR. The reliability of height and heigh velocity in the assessment of growth. Arch Dis Child 1991;66:833-7.

(Accepted 10 February 1992)

\title{
"Thirst strike": hypernatraemia and acute prerenal failure in a prisoner who refused to drink
}

\author{
Marie Neeser, Patrick Ruedin, \\ Jean-Pierre Restellini
}

\section{Institut Universitaire de Médecine Légale, Centre Médical Universitaire, 1211 Geneve 4, Switzerland Marie Neeser, assistant Jean-Pierre Restellini, head of prison medicine division}

\section{Division de Néphrologie,} Hôpital Cantonal

Universitaire, 1211 Geneve 4, Switzerland

Patrick Ruedin, consultant in nephrology

\section{Correspondence and} requests for reprints to: Dr Restellini.

BMF 1992;304:1352
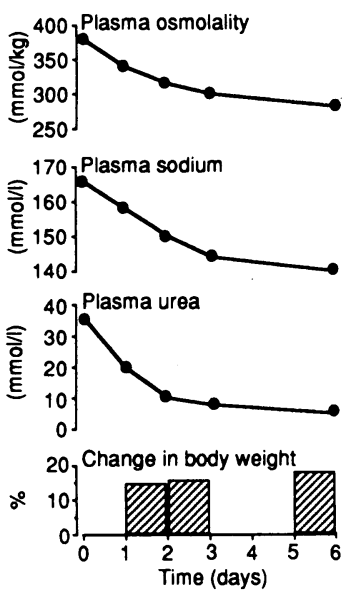

Changes in body weight (from value of $56 \mathrm{~kg}$ on admission) plasma urea concentration, sodium concentration, and osmolality during oral and parenteral rehydration
Hunger strikes - a refusal to eat food-are well known in prison medicine, but to our knowledge a "thirst strike" has not been described. We describe such a strike, which led to severe dehydration, hypernatraemia, and acute prerenal failure.

\section{Case report}

A 41 year old prisoner of sound mind was admitted for the third time to the maximum security hospital ward in Geneva after having completely refrained from drinking and eating for 13 days to protest against his solitary confinement. In 1983 he had refused food in another prison, and he had twice been voluntarily admitted to our ward after a complete fast. On both occasions, he had presented with severe dehydration and acute reversible uraemia.

On his latest admission the patient complained of thirst, asthenia, orthostatic vertigo, headaches, and intense abdominal and back pain, and he was oliguric. Physical examination showed emaciation $(56 \mathrm{~kg}$; height $174 \mathrm{~cm}$ ) decreased skin turgor, chapped lips, hypotonia of the eyeballs, dryness of the tongue, and diffuse abdominal tenderness. His pulse was regular at 78 beats/min and blood pressure was $110 / 70 \mathrm{~mm} \mathrm{Hg}$. He was conscious, well oriented, and presented only slight hesitations of language. Results of laboratory tests showed: haemoglobin $17 \cdot 5 \mathrm{~g} / \mathrm{l}$, plasma sodium 164 $\mathrm{mmol} / \mathrm{l}$, urea $37 \cdot 2 \mathrm{mmol} / \mathrm{l}$, creatinine $177 \mu \mathrm{mol} / \mathrm{l}$, and osmolality $380 \mathrm{mmol} / \mathrm{kg}$. The fractional excretion of sodium was $0 \cdot 21 \%$. After this strong willed patient finally agreed to parenteral rehydration he immediately started to drink. Treatment consisted of isotonic sodium chloride infusions since he still refused any energy intake. Biological values returned to normal after seven days (see figure) and the patient gained $10 \mathrm{~kg}$.

\section{Comment}

To our knowledge this is the first time that a "thirst strike" has been reported. This exceptional situation arose in a prisoner who wanted to use his body to influence the legal authorities.
In similar circumstances hunger strikes occur much more commonly, probably because they are easier to endure and more manageable. The voluntary refusal of liquid needs exceptional determination since thirst is one of the most powerful behavioural drives. ${ }^{1}$ The craving for water can become intense enough to dominate all other thoughts or sensations. ${ }^{2}$ Furthermore, thirst, regulated essentially by plasma osmolality, does not diminish so long as osmolar pressure stays high (more than $290-295 \mathrm{mmol} / \mathrm{kg}$ ).

Dehydration such as that seen in our patient usually occurs only in people involuntarily deprived of water and in those whose sensation of thirst is impaired, such as elderly people and patients with hypothalamic hypodipsia-hypernatraemia with or without dysregulation of vasopressin secretion..$^{14}$ Moreover, acute hyperosmolar states are associated with severe encephalopathy, whereas our patient presented only mild neurological disturbances.

We initially doubted this patient's claim not to have drunk for 13 days; nevertheless, he undoubtedly did undergo an extended period without drinking and as a result suffered hyperosmolar dehydration and acute prerenal azotaemia. His negative fluid balance was estimated to be 10 litres. In experimental hypernatraemia brain cells produce solutes called "idiogenic osmoles," and this protective mechanism might explain the mildness of his neurological symptoms.

The danger in cases such as this is not recognising the severity of the dehydration. Clinicians should suspend their disbelief, start investigations, and offer rapid treatment - without which a fatal outcome might ensue.

1 Robertson GL, Aycinena P, Zerbe RL. Neurogenics disorders of osmoregulation. Am F Med 1982;72:339-53.

2 Robertson GL. Abnormalities of thirst regulation. Kidney Int 1984;25:460-9.

3 Phillips PA, Rolls BJ, Ledingham JGG, Forsling ML, Morton JJ, Crowe MJ et al. Reduced thirst after water deprivation in healthy elderly men. $N$ Engl f Med 1984;311:753-9.

4 Hammond DN; Moll GW, Robertson GL, Chelmicka-Schorr E. Hypodipsic hypernatremia with normal regulation of vasopressin. $N$ Engl $\mathrm{g} \mathrm{Med}$ 1986;315:433-6

5 Pollock AS, Arieff AI. Abnormalities of cell volume regulation and their functional consequences. Am f Physiol 1980;239:F195-205.

(Accepted l October 1991)

\section{Correction}

Clinical trial with inactivated hepatitis $\mathbf{A}$ vaccine and recommendations for its use

An author's error occurred in this article by Anthea J Tilzey and colleagues (16 May, pp 1272-6). The third sentence of the las paragraph of the results section should read "Levels of IgA in parotid fluid and saliva correlated but IgG responses did not." 